\title{
Isolation and Characterization of Bis (2 - Methoxyethyl) Phthalate and Hexashydro-1 3 - Dimethyl - 4 - Phenyl - 1h - Azepine 4 - Carboxylic Acid from the Root of Cissampelos Owariensis (P. Beauv)
}

\author{
O.O. Efiom \\ Department of Chemistry, University of Abuja, Abuja-Nigeria
}

\begin{abstract}
The root of Cissampelos owariensis yielded two new additional compounds. These compounds were identified on the basis of spectroscopic analysis, here reported for the first time from the plant as bis (2-methoxy ethyl) phthalate and hexa hydro-1,3-dimethyl -4-phenyl-IH-azepine-4carboxylic acid
\end{abstract}

\section{INTRODUCTION}

The phytochemical investigation of the root and leaf extracts of $C$. owariensis yield the following alkaloids isochrodrondendrin, berberine and cycleanine(Southen, 1989).

Recently, we described the isolation and identification of two sesquiter terpene, to be $2 \mathrm{H}$ cyclopropa-naphthalene-2- one, 11a, 4,5,6, 7,7a ,7b octahydro- $1,1,7,7$ a tetramethyl, and $5(1 \mathrm{H})$ azulenone, 2,4,6,7,8 8a hexahydro 3,8dimethyl(-4-(1-methyl ethylidene respectively (Efiom et al, 2009).

The isolation of this interesting group of new compounds, combined with our taxonomic interest in the Menspermaneae as a household name in an African traditional medicine, stimulated further an investigation of the root of C. owariensis. Two new compounds bis (2methoxy ethyl) phthalate and he xahydro1,3-dimethyl(-4-phenyl-1H-azepine-4carboxylic acid have now been isolated along with other compounds.

\section{MATERIALS AND METHODS}

Materials; The root of $\mathrm{C}$. owariensis was collected in September 2006 from Gwagwa, Suleja, Nigeria and authenticated at the National Institute for Pharmaceutical Research and Development (NIPRD) Idu, Abuja, Nigeria. Voucher specimen has been deposited at the herbarium. IR $\left(\mathrm{cm}^{-1}\right)$ nujol as internal reference on 1310 spectrometer, MS; Kroto 80, EIMS using Hewlet Pack care ICMS, CC; MerkKiesel gel 60 ;( 230-400mesh) TLC and PTLC: precoated Merk Kiesel gel 60F 254( $0.25 \mathrm{~mm}$ and $100 \mathrm{~mm}$ respectively. TLC detector UV lamp (254to366Nm), Iodine vapour and Vanillin $/ \mathrm{H}_{2} \mathrm{SO}_{4} 1 \%$ w/V

Extraction:The dried pulverized root $(1 \mathrm{~kg})$ was extracted with $95 \%$ ethanol $\left(2 \mathrm{dm}^{3}\right)$, for six hours using soxhlet extractor. The extract was evaporated to dryness in rotatary evaporator to give $15 \mathrm{~g}$ residue.

Fractionation of Ethanolic Extract C.owariensis: Ethanol extract ( $5 \mathrm{~g})$ was absorbed in silica gel $5 \mathrm{~g}$ and loaded on column of silica gel. The column was then eluted using pump pressure and varying the eluent polarity ratios. The Elution with a mixture of ethyacetate in n-hexane $20 \%$ and the collection of $100 \mathrm{ml}$ portion. A total of 15 fractions were collected. The fractions were combined based on their $R_{f}$ values. The $R_{f}$ profile were found to be closely related 0.67 and 0.70 respectively.

The combined fractions were given an identification number $\mathrm{RB}_{1}$ and $\mathrm{RB}_{2}$. Fractions $\mathrm{RB}_{1}$ and $\mathrm{RB}_{2}$ were further purified using PTLC on silica gel [ethyl acetate/hexane (4:1)] to give yellow gum (227mg) and a brown gum (200mg) respectively. They were subjected to spectral analysis as follows: 
Characterization of Compound 1:IR: $\mathrm{v} \mathrm{cm}$ 1729163214341381 and $1070 \mathrm{GC}$ scan at 363(RT=4.789) EIMS (relative intensities $\% \mathrm{~m} / \mathrm{z}) \quad 195 \quad\left(\mathrm{M}^{+} 15 \%\right) 149\left(\mathrm{M}^{+} 100 \%\right) \quad 132$ $\left(\mathrm{M}^{+} 10 \%\right)$ 121( $\left.\mathrm{M}^{+} 4 \%\right) 104\left(\mathrm{M}^{+} 3 \%\right) 93\left(\mathrm{M}^{+} 3 \%\right)$ $\begin{array}{lllll}83 & \left(\mathrm{M}^{+} 2 \%\right) & 70\left(\mathrm{M}^{+} 11 \%\right) & 55\left(\mathrm{M}^{+} 12 \%\right. & \end{array}$ $\left(\mathrm{M}^{+} 12 \%\right)$ and $39\left(\mathrm{M}^{+} 2 \%\right)$

Characterization of Compound 2:IR: $\mathrm{V}\left(\mathrm{cm}^{-1}\right)$ $3500(-\mathrm{OH}$ of $\mathrm{COOH}), 1725(\mathrm{C}=\mathrm{O}$ of $\mathrm{COOH})$, $1640(\mathrm{C}=\mathrm{C}), 14611283$ and 1121. GC scan at 12 (RT=1.743), EIMS(relative intensity 5\%) $\mathrm{m} / 2247\left(\mathrm{M}^{+} 3 \%\right) 231\left(\mathrm{M}^{+} 11 \%\right) 223\left(\mathrm{M}^{+} 13 \%\right)$ $202\left(\mathrm{M}^{+} 10 \%\right) \quad 184\left(\mathrm{M}^{+} 21 \%\right.$ ) $168\left(\mathrm{M}^{+} 39 \%\right)$ $141\left(\mathrm{M}^{+} 42 \%\right) \quad 128\left(\mathrm{M}^{+} 29 \%\right) \quad 115\left(\mathrm{M}^{+} 54 \%\right) \quad 92$ $\left(\mathrm{M}^{+} 14 \%\right)$ 77( $\left.\mathrm{M}^{+} 100 \%\right)$ 64( $\left.\mathrm{M}^{+} 25 \%\right)$ 51( $\left.\mathrm{M}^{+} 35 \%\right)$ and $\left(\mathrm{M}^{+} 13 \%\right)$

\section{RESULTS AND DISCUSSION}

The roots of Cissampelos owariensis were extracted with $95 \%$ ethanol followed by CC over silica gel (see experimental). This procedure gave two compounds named bis (2-methoxy ethyl) phthalate (1) and hexahydro -1, 3dimethyl -4-phenyl -IH-azepine -4-carboxylic acid (2). Identification of the known compounds were based on their spectroscopic evidence and comparison data reported in the literature.<smiles>COCCOC(=O)c1ccccc1Cl</smiles>

Compound 1] The IR spectrum $\left(\mathrm{CCl}_{4}\right)$ showed carbonyl at $1729 \mathrm{~cm}$, typical of an aromatic ester (ArCOO-) (James et al, 1982). This is also supported by the presence of strong bond in the $\mathrm{C}-\mathrm{O}$ stretching at $1228 \mathrm{~cm}$. The unmistakable of a $(\mathrm{C}=\mathrm{C})$ group at $1632 \mathrm{~cm}$ is characteristic of aromatic compound. The MS exhibited at $\mathrm{m} / \mathrm{z}$ $149(100 \%)$ fragment mass ion, which is characteristic presence of phthalates (fig 1) corresponding to the simultaneous loss of a methoxy ethyl group to give phthalic acid anhydride moiety \{William , 1993 and Sastry, $1995\}$. The $\mathrm{m} / \mathrm{z}$ of phthalate as it represents loss of one side chain on the phthalate. The mass ion, $\mathrm{M}^{+}$which is not visible in the MS was expected at $\mathrm{m} / \mathrm{z} 282$ just as was reported in(fig1). The above spectral characteristics and comparison of the MS with the stored library mass spectral data and literature for phthalate were supportive of the fact that the compound is bis (2- methoxy ethyl) phthalate. Among the phthalates, di-noctylphthalate has previously been isolated from marine brown alga, Sargasum wightii as the major compound responsible for its anti bacterial activity (Honghung et al, 2007 and Luigton, 1997).



Figure 1 Mass spectrum of bis (2-methoxy ethyl) phthalate 
Compound 2 with molecular formula $\mathrm{C}_{15} \mathrm{H}_{21} \mathrm{O}_{2} \mathrm{~N}$ was shown by GCMS. It has two double bond equivalent which are easily identifiable from the IR spectrum, with carbonyl group absorbing at $1725 \mathrm{~cm}$ and a $\mathrm{C}=\mathrm{C}$ double bond at $1640 \mathrm{~cm}$. The bond at $1640 \mathrm{~cm}$ showed the aromatic nature of the compound, which is partly supported by mass spectrum at $\mathrm{m} / \mathrm{z}=77$ (base peak). The mass spectrum showed molecular ion $\mathrm{M}^{+}$at $\mathrm{m} / \mathrm{z} 247$. The fragment ion at (203-184) showed the loss of water molecule. The odd molecular ion at 247 also suggests a single nitrogen atom in the molecule of the compound. The high resolution mass spectrum of compound 2 gave the molecule mass as 247 corresponding to the $\mathrm{C}_{15} \mathrm{H}_{21} \mathrm{O}_{2} \mathrm{~N}$ as shown in fig2

Conclusion: The results had also shown some possible chemical constituents of the root of C.owariensis to which the local usage of the medicinal plant may be attributed (Efiom et al, 2009 and Akinniyi, 2005).The results also confirm the need to study the chemistry and biological activities of the root of $C$ owariensis that have before now not been investigated. This study could also be chemotaxonomically significant.

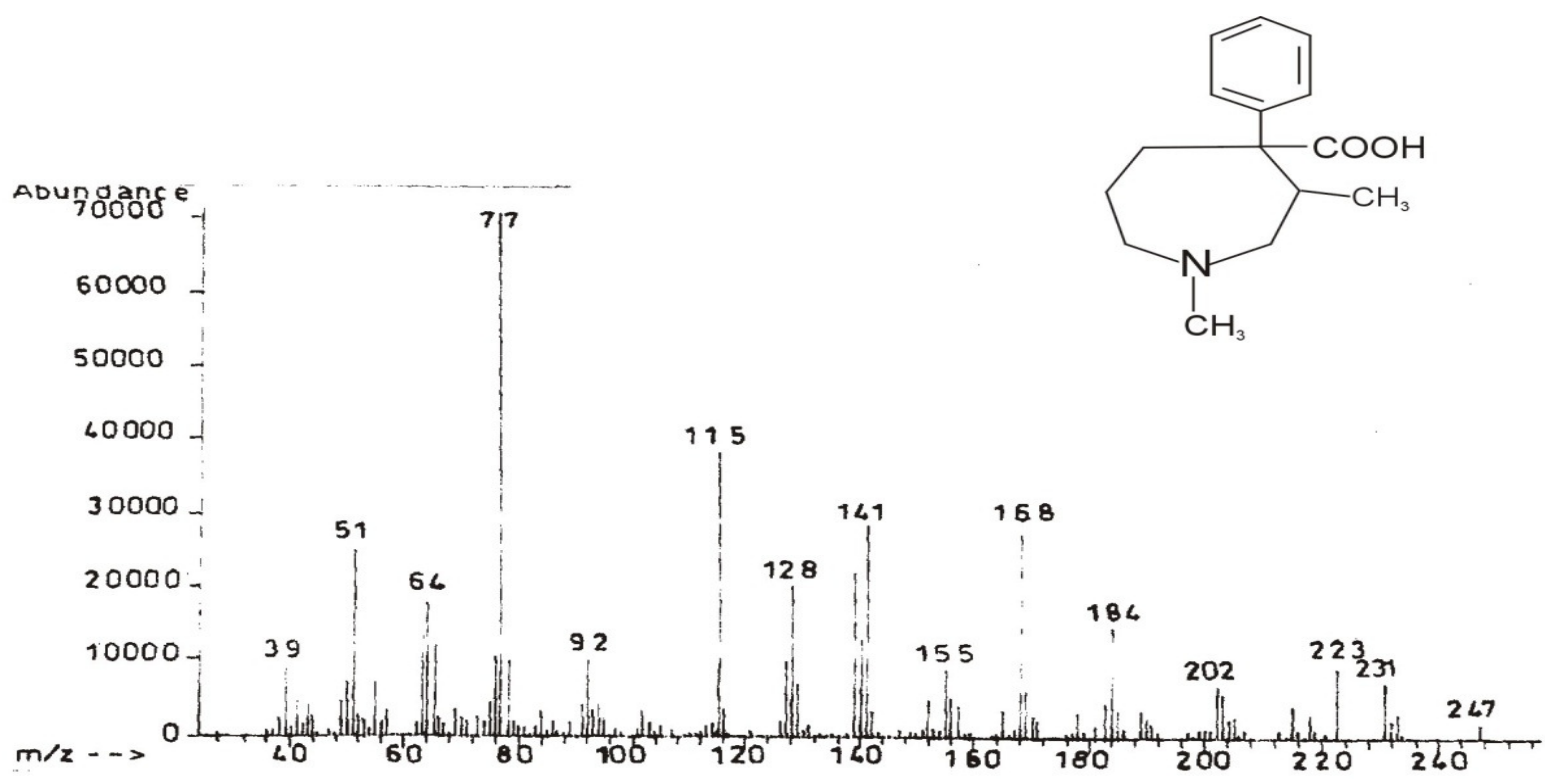

Figure 2: Mass spectrum of hexa hydro -1,3 - dimethyl -4- phenyl - $\mathrm{IH}$ - azepine -4- carboxylic acid

\section{REFERENCES}

Akinniyi, J A and EFIOM, O.O(2005); Antibacterial activities of Hexane and ethanolic extract of the root of ciessampelos

Owariensis . Biological and Environmental science. Journal for the tropic(Best) 2(1) 9193.

Christie, W.W. (1999); mass spectral of some miscellaneous artifact and additive.In: the lipid library scottish crop research institute(and MRS lipid Analysis unit) invergowrie Dundee (DD25DA) scotland
Efiom, O.O, Okwute, S.K, Okogun, J.I, and Orisadipe , A.T (2009), Sesquiterpenes from Cissampelos owariensis(P Beauv) root with antimicrobal and antiviral activity. Journal of chemical society of Nigeria vol 34 (2) 11-16.

Honghung, Le shitao Yu, Fusheng, Liu congxia xie and Luli (2007) synthesis of dioctyl phthalate using acid functionized ionic liquid as catalyst. Catalysis communication $8(11)$ 1759-1762.

Jame s, A.M, David, L.D, and Oscar. R R (1982); Experimental methods in organic 
Efiom; Isolation and Characterization of Bis (2 - Methoxyethyl) Phthalate and Hexashydro-1 3 - Dimethyl - 4 - Phenyl - 1h - Azepine 4 Carboxylic Acid from the Root of Cissampelos Owariensis (P. Beauv)

chemistry $3^{\text {rd }}$ edition saunder golda series London Pg. 106

Luigton, A W(1997); Diisononyl phthalatechronic toxicity and carcinogenicity in rats.food and chemical toxicology 35(2) 636.

Sastry, v. m and Rao, Co R K (1995) Dioctyl phthalate and anti-bacterial compound from the marine brown alga-sargassum wightii journal of applied phycology 7(2) 185-186.
Southern, Iw and Buckingham J (1989) dictionary of alkaloid Chapman hall, New York. Pg. 628

Williams H D and Fleming I (1973); Spectroscopic method in organic chemistry $2^{\text {nd }}$ Edition P sykes me grew-hill Book co UK Ltd 